\title{
Trust as the Antecedent of Strategic Choices from a Relational View Perspective
}

\author{
Dagmara Lewicka* \\ AGH University of Science and Technology \\ Krakow, Poland \\ *dagal@poczta.fm
}

\author{
Agnieszka Zakrzewska-Bielawska \\ Lodz University of Technology \\ Lodz, Poland
}

\begin{abstract}
The aim of the relational strategy is to select partners with whom cooperation will enable the creation of value. The success of an organization depends on the scope of cooperation with other entities. The article analyses the influence of interorganizational trust on the strategic choices of enterprises taking into account value creation appropriation, diversity of partners and interorganizational dynamics. The research was conducted on a representative sample of 400 enterprises operating in Poland and on international markets, which is representative of the company's size. The research results confirmed the important role of interorganizational trust as an antecedent of strategic choices. It plays an important role in the process of value creation, selecting partners for relationships, and influences the way relationships are created.
\end{abstract}

Keywords: trust, strategic choices, relational view perspective, polish enterprises

\section{INTRODUCTION}

The relational view perspective explains and provides theoretical foundations for understanding why organizations create and develop relationships and networks [1]. The relational management context leads to research on the essence of the relational strategy of enterprises and the strategic choices that are made within it. It has been shown that the key choices around which the content of the relational strategy is played includes the goal, the partner, the interorganizational dynamics and the way relations are created. An important research problem is the identification of antecedents of the strategic choices of enterprises.

The attention of researchers in this context focuses on interorganizational trust as one of the most important factors $[2,3]$. Interorganizational trust assumes that cooperating enterprises rely on each other in the belief that each party will fulfil its obligations in a competent, honest and rational manner, generating mutual benefits. In addition, the partner will not behave opportunistically, but will fulfil the contract and take actions that the trusting party expects. Trust in interorganizational relations to date has been analyzed in terms of strengthening interorganizational cooperation [4] the process of knowledge creation and exchange [5] and the dynamics of trust building depending on the duration of the relationship [6].

The authors emphasize that every relationship which contains some uncertainty requires trust. Trust is seen as both an antecedent and an intangible resource stimulating the competitiveness of an enterprise [7]. Trust has an influence on the effectiveness of cooperation, knowledge sharing and performance improvement $[8,9]$.

The model developed by Mayer, Davis, and Schoorman called -ABI was accepted in the study of inter-organisational relations [10]. The model pointed out three fundamental components of trust: ability, referring to the partner's skills, knowledge and experience, i.e. their competence in cooperation; benevolence, which applies to caring for the common good and a positive atmosphere of cooperation; and integrity, or the level of respect for the mutually accepted principles for cooperation.

There is a lack of research that would test the relationship between trust in interorganizational relations and the strategic choices of enterprises from a relational view perspective. Therefore, the purpose of this paper is to discern the relationship between the level of trust and its dimensions on strategic choices made within an enterprises' relational strategy.

\section{HYPOTHESIS DEVELOPMENT}

The degree of trust is the decisive criterion for choosing between a multitude of business alternatives. It is based on a subjective, graded probability of the occurrence of behaviours and actions undertaken by the other party in a given situation, and reduces the uncertainty accompanying mutual relations. The above were the premise for the formulation of hypotheses assuming the influence of interorganizational trust on the strategic choices presented in the figure below (fig. 1). Three choices were taken into account: How to create and appropriate value, type of partners and interorganizational dynamics, due to their apparently close relationship to trust.

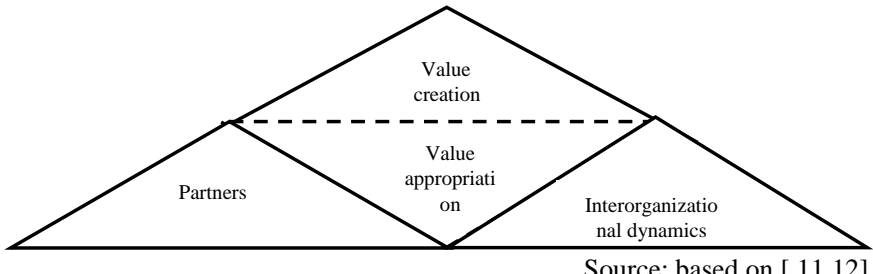

Fig. 1. Three strategic choices within a firm's relational strategyconceptual model. 
Considering the first strategic choice, value can be created according to the logic of the value chain and network value. The first of these includes a group of entities cooperating with each other in various areas, that are links in a wider value chain and suppliers, distributors and customers to each other. These relationships are transactional in nature and focus mainly on logistical synchronization, problems with exchange and unilateral learning [13]-In turn, the logic of value focuses on creating shared value and benefits for all participants in the network [14]. Creating value is divided between collaborating entities, which may be associated with a tendency to maximise or protect it [15]. It can be assumed that a higher level of trust will incline partners to take action oriented toward maximizing value, and a lower level toward protecting it. The results of research confirm that trust in partners has a significant impact on the process of creating and exchanging knowledge. It helps in overcoming the tension between the willingness to share knowledge and the desire to protect it [5]. This was then the premise for the formulation of hypothesis 1:

H1. Trust is the antecedent to the choice of how to create and appropriate value in a relational strategy in the sense that (a) value is created in a network of values and (b) appropriated through maximization are choices when there is a higher level of interorganizational trust.

In the subject literature, relations are perceived as one of the most important resources, building the value of the enterprise and its competitive advantage [16]. This resource is the basis for an enterprise's market power, reducing uncertainty and stabilising its market position in the long term. Participation in a network, i.e. a group of entities between which there are links of strategic importance, provides access to information about technology, the ability to learn more quickly, risk and cost sharing. Integration of the enterprise's own resources with the resources of partners makes them more unique, which enables, among other things, generation of greater relational rents. Therefore, a key element of interorganizational relations management is building and managing a portfolio of heterogeneous relations. An entity may collaborate with a differentiated group of partners by establishing various types of relations, competitive and noncompetitive or collaborate with a limited group of partners. This forms the basis for the next hypothesis, namely:

$\mathrm{H} 2$. Trust is the antecedent to choosing the type of partners in a relational strategy in the sense that the higher the level of interorganizational trust, the more diverse the partners are.

Cooperation based on trust is based on the belief that it will lead to the organization obtaining significant benefits such as cost reduction, knowledge acquisition, increasing innovation potential, and many others [17]. Trust is therefore considered a necessary and important factor for voluntary cooperation [18]. Many authors emphasise the important role of trust as a factor supporting relations in a strategy of coopetition $[19,20]$. However, in this system, trust is only one of the factors that may explain the tendency to establish relations based on coopetition.

Therefore, one can conclude that cooperation on the basis of partnership is characterised by a higher level of trust in partners than in the case of relations of a different nature [e.g.17,21] which provides the basis for the formulation of hypothesis 3 .

H3. Trust is the antecedent to the choice of an interorganizational dynamics in a relational strategy in the sense that (a) partnership cooperation and (b) cooperation become choices when there is a higher level of interorganizational trust.

\section{METHODS}

In order to test the hypothesis, an empirical study was conducted from January to the end of May 2019 on a group of 400 entities operating in Poland. The sample is representative in terms of employment size and Polish Classification of Activity. In this group, there are entities with qualities ascribed to small companies (i.e. with 10-49 employees), medium-sized companies (i.e. with 50-249 employees) as well as those whose are large companies (i.e. with 50-249 employees). The sampling frame was the database of the National Business Register (REGON) and the research was carried out using the method of probabilistic layered random selection. The survey was conducted using a questionnaire by the CATI (Computer Assisted Telephone Interview) method. The questionnaire was a structured and standardized. Respondents were either owners or top management. The studied population were mainly mature entities, i.e. entities that have been operating on the market for over twenty years. They therefore have appropriate experience in creating, developing or withdrawing from interorganizational relations. The impact of trust on taking up strategic choices was one of the partial issues.

Figure 2 presents the most important information regarding the research process.

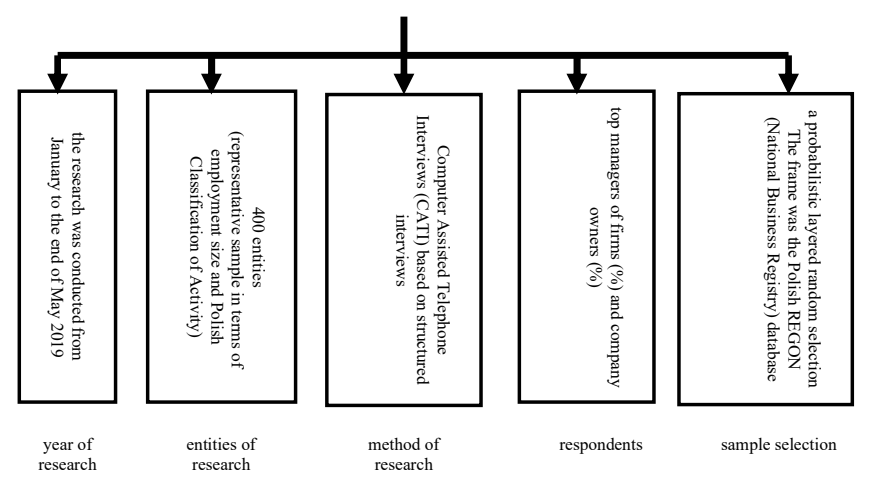

Source: author's elaboration.

Fig. 2. The research process.

We analyzed the reliability of the scales using Cronbach's alpha and identified the relationship between strategic choices made within the enterprise's relational strategy and interorganizational trust using structural equation modelling, which allowed analysis of the dependency between the hidden variables [22].

For estimation of the parameters, we used the ML (maximum likelihood) method (Westland 2010), evaluated the fit of the model by use of measures of quality factor matching such as the Chi squared to df ratio $(\chi 2 / \mathrm{df})$, the root mean 
square error of approximation (RMSEA), the goodness-of-fit index (GFI), and the adjusted goodness-of-fit index (AGFI)

\section{A. Measures}

Particular strategic choices and interorganizational trust were measured using a seven-point Likert scale, with anchors ranging from strongly disagree (1) to strongly agree (7). Because of the use of a Likert scale, the items measured respondents' perceptions rather than measuring objective facts.

To measure trust, an eight-item scale was used $(\alpha=.98)$ (e.g., "We trust that our partner pursues common goals", "We trust that the partner, based on their competences, is able to meet the conditions of cooperation", "We trust that as a result of cooperation, we will obtain benefits exceeding the outlays").

In turn, an eleven-item scale was used to measure the logic of value creation and appropriation. The scale consists of four subscales. The first, comprised of two items, focused on creating value by the logic of a value chain, $\alpha=.88$ (e.g., "“ Value in our company is created primarily on the basis of vertical / sequential interdependence (i.e. on the supplierrecipient line), bringing us non-financial benefits"); the second, comprised of two items, focused on creating value by the logic of a value network, $\alpha=.97$ (e.g., "Value in our company is created jointly by cooperating with selected (key for us) suppliers, customers, competitors and other market entities, which brings non-financial benefits to each of us"); the third, comprised of four items, focused on value appropriation - mechanisms for protecting value, $\alpha=.92$ (e.g., "We protect part of the value created jointly with our partners through contractual clauses"); the fourth, comprised of three items, focused on value appropriation - mechanisms for maximizing value, $\alpha=.85$ (e.g., "We maximize value by having resources that complement partners' resources").

To measure the second strategic choice - partners, a sixitem scale was used ( $\alpha=$.77) (e.g., "Our company constantly maintains relations with various entities", "We actively and systematically develop cooperative relations with key suppliers").

To measure the third strategic choice, a seven-item scale was used to measure interorganizational dynamics. The scale consists of three subscales. The first, comprised of two items, focused on transactional cooperation $\alpha=.57$ (e.g., "Our cooperation with customers is primarily of the following nature transactional"); the second, comprised of two items, focused on partnership cooperation, $\alpha=.6$ (e.g., "Our cooperation with customers is primarily of the following nature partner"); the third, comprised of four items, focused on coopetition $\alpha=.82$ (e.g., "If competitors offer cooperation, we accept it if it is legal and advantageous").

\section{FINDINGS}

First of all, we examined the relationship between trust and value creation and appropriation. The model fit the data adequately, which is presented in Table 1. Results from structural equation modelling showed that trust has a stronger influence on value creation in a value network $(\beta=.38, \mathrm{p}<$ $.01)$ and a weaker on in a value chain $(\beta=.23, \mathrm{p}<.01)$.

TABLE I. PARAMETERS OF THE SEM MODEL 1

\begin{tabular}{|l|l|l|}
\hline \multicolumn{3}{|c|}{ Evaluation of the SEM model } \\
\hline$\chi 2 /$ df & 1.948 & $\max .2 .00$ \\
\hline RMSEA & 0.099 & $\max .0 .10$ \\
\hline AGFI & 0.899 & $<0.90 ; 1.00>$ \\
\hline GFI & 0.940 & $<0.90 ; 1.00>$ \\
\hline
\end{tabular}

Figure 3 presents the following relationships.

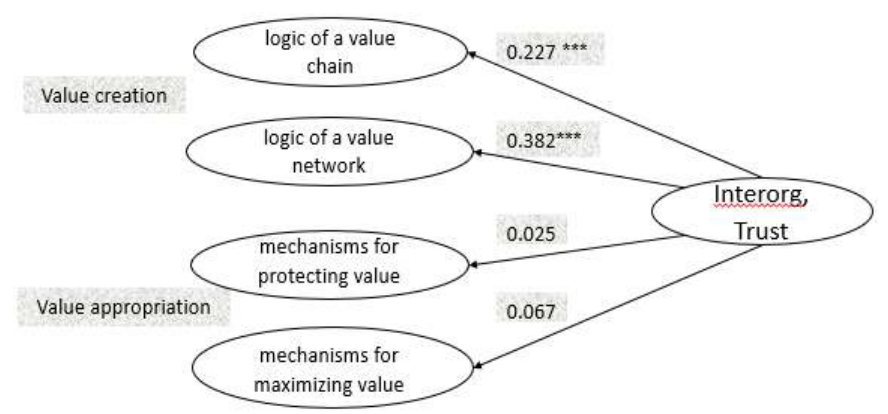

Source: author's elaboration.

Fig. 3. Structural model depicting the relationship between interorganizational trust and the choice of value creation and appropriation.

The hypothesis can be partially confirmed. With a higher level of interorganizational trust, value is created through a value network logic. Trust is an antecedent to creating value in a network that is stronger than in a value chain. The influence of trust on value appropriation turned out to be statistically insignificant.

In the next step, we examined the relationship between trust and the selection of partners. The model fit the data adequately, which is presented in Table 2. Results from structural equation modelling showed that trust has a strong influence on the selection of partners $(\beta=.69, \mathrm{p}<.01)$.

TABLE II. PARAMETERS OF THE SEM MODEL 2

\begin{tabular}{|l|l|l|}
\hline \multicolumn{3}{|c|}{ Evaluation of the SEM model } \\
\hline$\chi 2 /$ df & 1.983 & max. 2.00 \\
\hline RMSEA & 0.099 & max. 0.10 \\
\hline AGFI & 0.899 & $<0.90 ; 1.00>$ \\
\hline GFI & 0.940 & $<0.90 ; 1.00>$ \\
\hline
\end{tabular}

Fig.4 presents the following relationship.

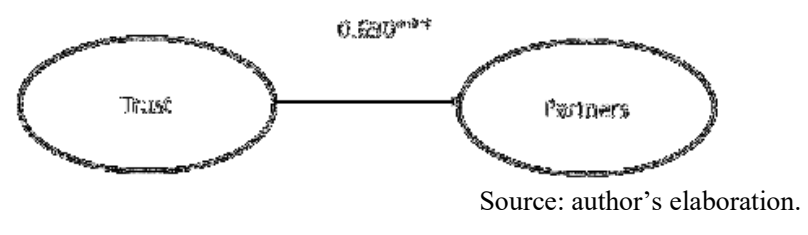

Fig. 4. Structural model depicting the relationship between interorganizational trust and the choice of partners. 
The model fits, therefore the $\mathrm{H} 2$ hypothesis can be confirmed.

In the next step, we examined the relationship between trust and interorganizational dynamics. The model fit the data adequately, which is presented in Table 3 . The results from structural equation modelling showed that trust has the strongest influence on partnership cooperation $(\beta=.65, p<$ $.01)$, significantly less on transactional cooperation. The impact of trust on coopetition is not statistically significant.

TABLE III. PARAMETERS OF THE SEM MODEL 3

\begin{tabular}{|l|l|l|}
\hline \multicolumn{3}{|c|}{ Evaluation of the SEM model } \\
\hline$\chi^{2 / \mathrm{df}}$ & 1.983 & $\max .2 .00$ \\
\hline RMSEA & 0.0985 & $\max .0 .10$ \\
\hline AGFI & 0.953 & $<0.90 ; 1.00>$ \\
\hline GFI & 0.916 & $<0.90 ; 1.00>$ \\
\hline
\end{tabular}

Fig.5 presents the following relationship.

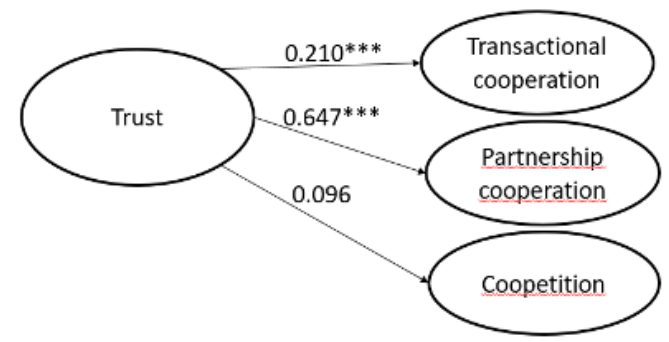

Fig. 5. Structural model depicting the relationship between interorganizational trust and the choice of interorganizational dynamics.

The model fits, therefore, the $\mathrm{H} 3$ hypothesis can be confirmed.

\section{CONCLUSIONS}

From a theoretical perspective, our paper contributes to the literature of strategic management by identification of a relationship between trust and strategic choices made within an enterprise's relational strategy. Trust is an antecedent of: the choice of value creation - with a higher level of interorganizational trust, value is created through value network logic, while with a lower level of trust, through chain value creation. Trust does not affect the appropriation of value;

the choice of partners - the higher the trust, the greater the number of cooperation partners;

the choice of interorganizational dynamics - the higher the level of trust between organizations, the more partnershiporiented the cooperation is.

From a practical perspective, our paper indicates how trust influences strategic choices, stimulating cooperation and creating greater value for partners. Therefore, it is worthwhile to maintain and strengthen trust in interorganizational relations.

\section{LIMITATION OF THE STUDY AND FURTHER RESEARCH}

The research approach adopted is not free from limitations, which may include limitations of the research method used (subjectivity in the respondents' statements). Survey results, i.e. opinions of respondents, are declarative in nature, which undoubtedly is also a limitation of the survey. This is especially true when both independent and dependent variables were obtained in the same way. Moreover, the results obtained relate to enterprises based in Poland, i.e. within a single country, even if some of them also operate in the global marketplace

Among directions for further research, it is worth mentioning comparative studies in different countries and cultures. Moreover, it would be worthwhile to extend the model by performance (financial and non-financial effects obtained from the relational strategy realization).

\section{REFERENCES}

[1] J.H. Dyer, H. Singh, W.S. Hesterly. "The relational view revisited: A dynamic perspective on value creation and value capture", Strategic Management Journal, vol. 39, no. 12, pp. 3140-3162. 2018.

[2] J. Kang. "Understanding the Roles of Trust at Different Stages in Strategic Alliances: A Theoretical Review", Business Management Dynamics, vol.4, no. 3, pp. 1-14. 2014.

[3] D. Lavie, P. Haunschild, P. Khanna. "Organizational differences, relational mechanisms, and alliance performance", Strategic Management Journal, vol. 33, no. 13, pp. 1453-1479. 2012.

[4] B. McEvily, V. Perrone, A. Zaheer. "Trust as an Organizing Principle", Organization Science, t. 14, nr 1, pp. 91-103. 2003.

[5] M. Bogers. "The open innovation paradox: knowledge sharing and protection in R\&D collaborations", European Journal of Innovation Management, vol. 14, no. 1, pp. 93-117. 2011.

[6] L. Zhang, T.Q. Peng, Y.P. Zhang, X.H. Wang, and J.J. Zhu. "Content Or Context: Which Matters More In Information Processing On Microblogging Sites," Computers in Human Behavior(31), pp. 242249. 2014.

[7] T. Savilainen, P.L. Fresno. "Trust as intangibleasset: Enablingintelectual capital developmentby leadershipfor vitalityand innovativeness", Electric Journal of Knowledge Management, vol. 11, no.3, pp244-255. 2013.

[8] R. Bachmann, A.C. Inkpen. "Understanding institutional-based trust building processes in inter-organizational relationships", Organization Studies, vol. 32, no. 2, pp. 281-301. 2011.

[9] C.S. Burke, D.E. Sims, E.H. Lazzara, E. Salas. Trust in leadership: a multi-level review and integration, "Leadership Quarterly", t. 18, nr 6, s. 606-632. 2007.

[10] M.D. Baer, A. Colquitt. "Why Do People Trust" In The Routledge Companion to Trust. Ed . by R. H. Searle, A.-M. I. Nienaber, S. B.Sitkin, 163-182. New York Routledge. 2018.

[11] A. Zakrzewska-Bielawska. Seeking the Content of the Relational Strategy: Conceptual Framework, "International Journal of Management and Applied Science", vol. 3, no. 4, pp. 67-74. 2017.

[12] A. Zakrzewska-Bielawska. Recognition of relational strategy content: insight from the managers' view, "Eurasian Business Review", vol. 9, no. 2, pp. 193-211. 2019.

[13] A. Zakrzewska-Bielawska. Tworzenie i apropriacja wartości jako cel strategii relacyjnej przedsiębiorstwa, Prace Naukowe Uniwersytetu Ekonomicznego we Wrocławiu Nr 444, , pp. 609-622. 2016.

[14] W. Czakon. Koopetycja w rozwoju przedsiebiorstw High- Tech in: A. Zakrzewska-Bielawska (red.), Koopetycja w rozwoju przedsiębiorstw high-tech. Determinanty i dynamika, Placet, Warszawa. 2014.

[15] W. Czakon. Sieci w zarzadzaniu strategicznym, Oficyna Wolters Kluwer business, Warszawa. 2012. 
[20] M.G. Devetag. Coordination and trust as prerequisites of coopetition. Experimental evidence. [in:] Dagnino, GB and E Rocco (Eds.), Coopetition strategy - Theory, experiments and cases, Routledge, New York, pp. 274-289. 2009.

[21] E.H. Klijn, V. Sierra, T. Ysa, E. Berman., J. Edelenbos, D.Y. Chen. The influence of trust on network performance in Taiwan, Spain and the Netherlands: A cross country comparison, "International Public Management Journal”, vol. 19, no. 1, pp.111-139. 2015.

[18] D. Lewicka, K. Krot, "The model of HRM-trust-commitment relationships", Industrial Management \& Data Systems, Vol. 115 No. 8, pp. 1457-1480. 2015.

[19] A. Brolos. Innovative coopetition: The strength of strong tie, "International Journal of Entrepreneurship and Small Business", vol. 8, no.1, pp.110-134. 2009.

[22] N.K. Bowen, S. Guo. Structural equation modeling, Oxford University Press, Oxford. 2011. 